\title{
TWO TRAJECTORIES IN THE NEOLITHIZATION OF EURASIA: POTTERY VERSUS AGRICULTURE (SPATIOTEMPORAL PATTERNS)
}

\author{
Yaroslav V Kuzmin \\ Institute of Geology \& Mineralogy, Siberian Branch of the Russian Academy of Sciences, Novosibirsk 630090, Russia. \\ Email: kuzmin@fulbrightmail.org.
}

\begin{abstract}
Data on the emergence of pottery and agriculture in Eurasia were analyzed from the view of their spatiotemporal relationship. It was found that there are 2 major types of association between pottery and agriculture: 1) East Asian, with pottery as the main criterion of the Neolithization; and 2) Levantine, with agriculture as the phenomenon most closely related to the emergence of the Neolithic. Some regions of Eurasia have intermediate characteristics. The concept of a single area for pottery origin in eastern Eurasia and its subsequent spread to the west, still used by some scholars, is the revival of the old diffusionist paradigm and does not seem to advance the analysis of the Neolithization process. If the wheat/barley agriculture definitely originated in the Levantine "core" and spread toward Anatolia and central/western Europe, it is impossible to apply the same approach to pottery. The latest developments in chronology of the earliest ceramics in China, one of the key regions in the world in terms of the origin of pottery-making, are critically evaluated.
\end{abstract}

\section{INTRODUCTION}

The issues of Neolithization and the spatiotemporal features of the pottery/agriculture spread in Eurasia are among the most hotly debated in Old World archaeology (e.g. Jordan and Zvelebil 2009; Kuzmin et al. 2009; Hartz et al. 2011; Price and Bar-Yosef 2011). The term "Neolithic" was originally coined by Sir John Lubbock who indicated polished tools and to some extent pottery and agriculture as the main criteria of this period (Lubbock 1878). Later on, agriculture was accepted as the main benchmark of the Neolithic (e.g. Childe 1935:7). Discussion of this issue can be found in several sources, including Thomas (1993) and Kuzmin (2010a). As a result, there is an ambiguity with the definition of the term "Neolithic" in Eurasia: while in Levant and Europe it means first of all the presence of agriculture, in East Asia and adjacent regions pottery is the main criterion for the determination of the Neolithic (see discussion in Kuzmin 2010a,b). In order to understand the spatiotemporal relationship between pottery and agriculture in prehistoric Eurasia at the first degree of approximation, information about the timing of their appearance in key regions was collected and analyzed. This article presents the results of the study and its initial interpretations.

\section{MATERIAL}

Georeferenced data on the chronology for the appearance of agriculture (i.e. plant cultivation) and pottery were collected from published sources for Eurasia (Table 1). It should be emphasized that only regions with an early presence of both phenomena were selected, because in significant portions of northern Eurasia agriculture was introduced either quite late (in Bronze and Iron ages) or never practiced (see Figure 1). The values are expressed in calendar ages before present (cal BP) for the appearance of pottery $\left(A_{p o t}\right)$ and the invention/introduction of agriculture $\left(A_{\text {agr }}\right)$; the difference between them is therefore $A_{\text {pot-agr }}$ (Table 1). After the GIS-based mapping, the localities with both $A_{\text {pot }}$ and $A_{\text {agr }}$, and their $A_{\text {pot-agr }}$ values, were positioned, and isolines were generated for visualization by simple approximation between points.

(C) 2013 by the Arizona Board of Regents on behalf of the University of Arizona 
Y V Kuzmin

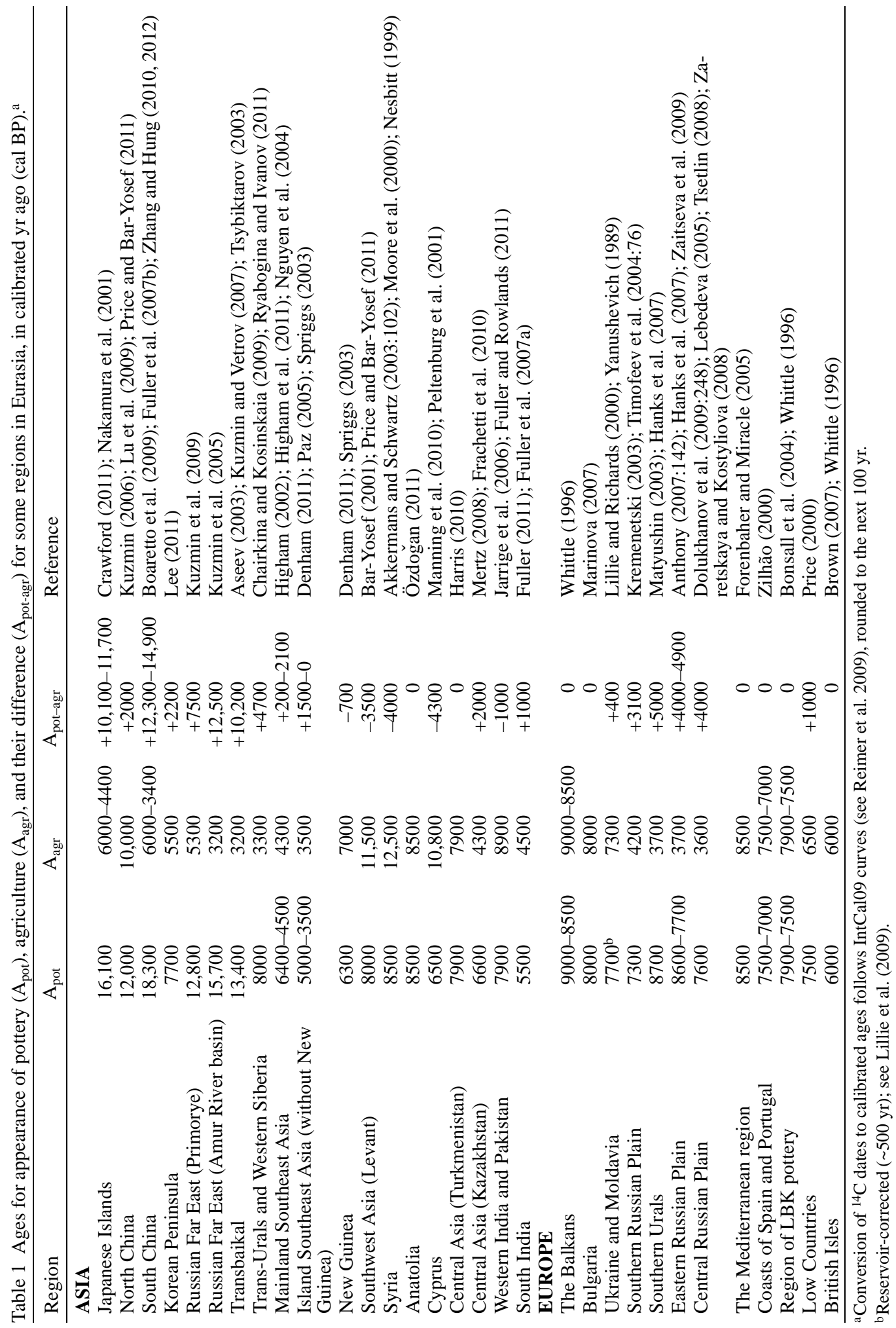




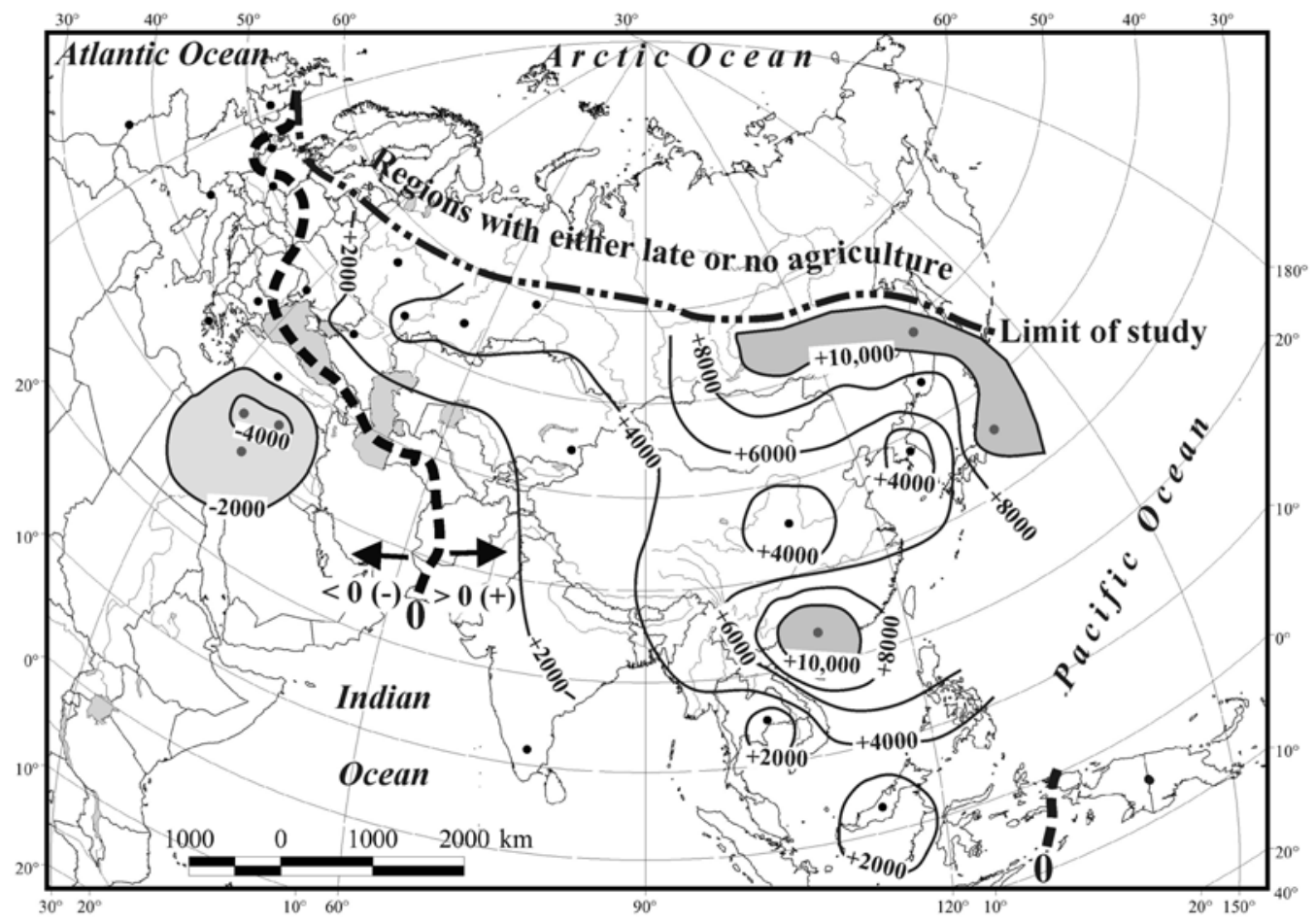

Figure 1 Isolines showing the temporal relationship between the appearance of pottery and agriculture $\left(\mathrm{A}_{\mathrm{pot}-\mathrm{agr}}\right)$ in Eurasia; key regions are indicated by dots, see original data in Table 1 . Dark gray areas: the most positive $A_{\text {pot-agr }}$ values; light gray area: the most negative $\mathrm{A}_{\mathrm{pot}-\mathrm{agr}}$ values.

\section{RESULTS AND DISCUSSION}

\section{Relationship Between Appearances of Pottery and Agriculture in Eurasia}

The spatiotemporal relationship between the 2 major criteria of Neolithization, pottery and agriculture, can be described as follows. For East Asia, the $A_{\text {pot-agr }}$ varies from about $+13,000$ to $+2000 \mathrm{yr}$; the extremely large positive $A_{\text {pot-agr }}$ values for southern China, the Japanese Islands, and the Amur River basin of the Russian Far East are noteworthy (Figure 1). In mainland Southeast Asia, the value is about $+200-2100 \mathrm{yr}$, while in island Southeast Asia it is about $+1500-0$ yr. In different parts of Siberia, the $A_{\text {pot-agr }}$ varies from $+10,200 \mathrm{yr}$ (Transbaikal) to $+4700 \mathrm{yr}$ (Trans-Urals and western Siberia). A similar trend is common for some parts of central Asia (Kazakhstan, $+2000 \mathrm{yr}$ ) and southern India $(+1000 \mathrm{yr})$. For eastern Europe, the $\mathrm{A}_{\mathrm{pot}-\mathrm{agr}}$ values have the same pattern as East Asia: $+3100 \mathrm{yr}$ for the southern Russian Plain; +5000 yr for the southern Urals; +4900-4000 yr for the eastern Russian Plain (middle and lower courses of the Volga River); and $+4000 \mathrm{yr}$ for the central Russian Plain (Figure 1).

For the Near East, the $A_{\text {pot-agr }}$ values are always negative: about $-3500 \mathrm{yr}$ for the Levant; $-4000 \mathrm{yr}$ for Syria; and $-4300 \mathrm{yr}$ for Cyprus (Figure 1). Further west (and sometimes northeast), the $\mathrm{A}_{\mathrm{pot} \text {-agr }}$ is almost equal to zero because agriculture and pottery were brought together as a "Neolithic package.” These regions include Anatolia and Turkmenistan in Asia; the Balkans and Bulgaria, the Mediterranean and Iberian coasts, the regions with LBK pottery (primarily Hungary, Croatia, Serbia, Austria, southern and central Germany, and the Czech Republic), and the British Isles, all in Europe. 


\section{Y V Kuzmin}

There are slightly positive $A_{\text {pot-agr }}$ values for the Low Countries (northern France, Belgium, and the Netherlands: $+1000 \mathrm{yr}$ ); and Ukraine and Moldavia (+400 yr). The situation for northern Europe (northern part of Germany and Poland, Denmark, and Fennoscandia) is more complicated and without a clear trend (e.g. Zvelebil 1998; Hartz et al. 2011), and should be the focus of future study.

Based on the data presented, 2 major trajectories in the Neolithization of Eurasia can be established. In most parts of Asia where pottery definitely preceded agriculture, the 'East Asian' scenario with positive $A_{\text {pot-agr }}$ values is common (Figure 2). In southwest Asia and central/western Europe, the 'Levantine' scenario with negative $A_{\text {pot-agr }}$ values prevails. Some parts of eastern Europe and central Asia (Turkmenistan) were also influenced by the Levantine agricultural core (Figure 2). A similar picture is presented by Fuller and Rowlands (2011:38-42) who plotted the chronology for the earliest pottery and agricultural complexes in Eurasia and northern Africa.

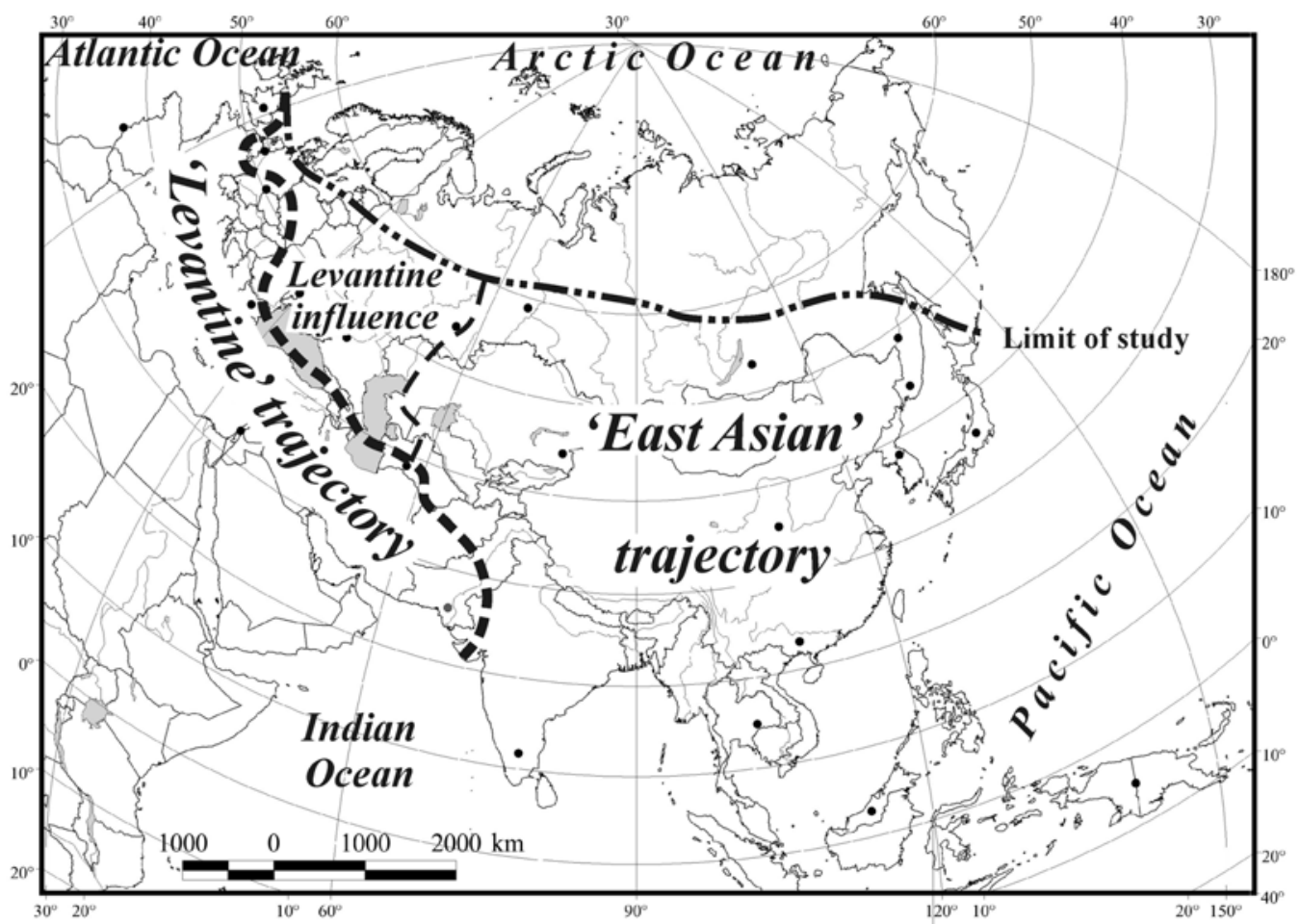

Figure 2 Location of regions belonging to 2 major trajectories in the Neolithization of Eurasia

When a spatiotemporal analysis for the appearance of pottery and agriculture in Eurasia is conducted, there should be no a priori assumptions in terms of the mechanism of pottery emergence and spread. While it is plausible to model the diffusion of wheat/barley-based agriculture from the Levantine 'core' to Asia Minor and Europe with the help of ${ }^{14} \mathrm{C}$ dates (e.g. Clark 1965; Gkiasta et al. 2003; Pinhasi et al. 2005; Russel 2004; see also the latest examples: Lemmen et al. 2011; Bocquet-Appel et al. 2012), the application of similar approach to pottery does not seem correct. It was repeatedly shown that the Childean diffusionist paradigm (e.g. Childe 1954:238-44) is unable to explain the appearance of several important cultural phenomena in Europe (e.g. Renfrew 1969:153, 1973; see also Trigger 2006:259-60). 


\section{Two Trajectories in the Neolithization of Eurasia}

Some scholars, however, still employ the diffusionist approach when attempting to understand the "roots" of eastern, central, and western European pottery, and continue to derive its origins from the eastern regions of Eurasia (e.g. Davison et al. 2006, 2007; Dolukhanov and Shukurov 2004; Dolukhanov et al. 2009; Piezonka 2011). In terms of eastern Europe, the localization of the "center" of origin for hunter-gatherer pottery in the middle course of the Volga River from where it spread throughout the Russian Plain (Davison et al. 2007:11, Figure 4f; see also Piezonka 2011; Hartz et al. 2012) is unproven by solid archaeological data (e.g. Tsetlin 2008; Vybornov 2008; Tsvetkova 2011). Before the genetic relationship between the early pottery types (Elshanka [Yelshanian] and Verkhnevolzhskaya [Upper Volga]) and the later ones (Narva, Valdai [Valday], and Serteya [Serteja]) is explicitly shown, any modeling would be unhelpful. Therefore, the use of the pottery origin concept in a single place and its subsequent dispersal in Eurasia (i.e. the process of Neolithization) is an oversimplification of cultural processes (see Kuzmin 2009:152; Kuzmin et al. 2009:892-4).

\section{The Age of the Earliest Pottery in China (the Latest Developments)}

Recently, Wu et al. (2012) published new data on the chronology of Xianrendong Cave in southern China. According to them, the ${ }^{14} \mathrm{C}$ age of the earliest pottery-bearing component of the Western Section is $\sim 16,170-17,420 \mathrm{BP}$, and of the Eastern Section, 16,100-17,460 BP. If true, these dates would make the pottery from Xianrendong significantly older compared to that from Yuchanyan Cave in the same large region, with associated ${ }^{14} \mathrm{C}$ dates of $\sim 14,800 \mathrm{BP}$ (Boaretto et al. 2009). However, some critical comments are necessary before acceptance of the pottery from Xianrendong Cave as the oldest in southern China in particular, and in the world in general.

The most complicated situation is still observed for the Western Section of Xianrendong where the disturbance of cultural layers and subsequent inversions in ${ }^{14} \mathrm{C}$ chronology were detected previously (MacNeish et al. 1998:39; see also Kuzmin 2006:365). Unfortunately, the new study by Wu et al. (2012) was unable to overcome the existing problems. First of all, no artifacts were collected during the cleaning up of the profiles at Xianrendong Cave (Wu et al. 2012:1697), and it is impossible to ascertain that the bone samples collected by Wu et al. (2012) are directly associated with the potsherds. This is in contrast to a previous study (MacNeish et al. 1998) when researchers conducted small-scale excavations and obtained reliable material for ${ }^{14} \mathrm{C}$ dating in direct association with the earliest pottery.

Second, the treatment of some ${ }^{14} \mathrm{C}$ dates obtained previously (see MacNeish et al. 1998; MacNeish 1999) seems to be biased. For example, the ${ }^{14} \mathrm{C}$ value of 12,530 $\pm 140 \mathrm{BP}$ (BA95145) from Layer 3C1A, which was found to be the single reliable age estimate for this stratum (MacNeish et al. 1998: 39), is not included in the list of ${ }^{14} \mathrm{C}$ dates; the rest of the ${ }^{14} \mathrm{C}$ values from this layer are significantly older, 14,240-16,340 BP (see Wu et al. 2012:1698-9, Table 1). Some other ${ }^{14} \mathrm{C}$ ages which do not fit the site's chronology are determined as outliers: 15,180 BP from Layer 3C2; 18,520 BP from Layer 3C1B; and 12,420 BP from Layer 3B2 (Wu et al. 2012:1699). It should be mentioned that the ${ }^{14} \mathrm{C}$ values from layers $3 \mathrm{C} 2$ and 3B2 were generated on relatively large pieces of human bones (weight from 1.1 to $9.1 \mathrm{~g}$; see MacNeish and Libby 1995:75), and discrepancies in their age relationship with the site's stratigraphy and other ${ }^{14} \mathrm{C}$ dates from these layers, in my opinion, show clearly the disturbed nature of cultural deposits at the Western Section as established previously (see MacNeish et al. 1998). Nevertheless, both this information and a critical evaluation of ${ }^{14} \mathrm{C}$ dates from Xianrendong Cave (Kuzmin 2006:365) were ignored by Wu et al. (2012).

Third, the micromorphological study of cultural deposits comprising the Eastern Section [Profile] of Xianrendong Cave resulted in the conclusion that “...it seems that most of the accumulation of the deposits in the Eastern Profile of the site do not represent in place human occupations or even occu- 


\section{Y V Kuzmin}

pation in this space” (Wu et al. 2012, Supplementary Material S2, p 21; see also Wu et al. 2012: 1698). This makes the series of ${ }^{14} \mathrm{C}$ dates from the Eastern Section very unreliable, and they should be rejected because they came from disturbed contexts and thus do not represent material for ${ }^{14} \mathrm{C}$ dating collected in situ.

Recently, Liu and Chang (2012) accepted the early age of pottery ( 13,080 BP) from the Hutouliang site in northern China following Yasuda (2002), and claimed it as the earliest pottery-bearing complex in the region. They indicated that the ${ }^{14} \mathrm{C}$ date was obtained on the pottery itself (Liu and Chang 2012:50), but this seems to be a misreading of Yasuda's (2002:127) original information: “The date for the pottery yielding stratum from the Hutouliang is $13,080 \pm 200{ }^{14} \mathrm{C}$ yr BP $(16,300-14,700 \mathrm{cal}$. yrs. BP) (GrA-10460, Yasuda, unpublished)" (italics are mine). No record about the material dated exists in the archive of the AMS Laboratory of Groningen University (the Netherlands) where this ${ }^{14} \mathrm{C}$ value was measured ( $\mathrm{J}$ van der Plicht, personal communication, 2005).

As noted before (Kuzmin 2006:366), this ${ }^{14} \mathrm{C}$ date is highly dubious and cannot be taken into account before more information is provided. No details about the stratigraphy of the Hutouliang site are given in the primary source (Guo and Li 2002). It is surprising that in this publication several pages are devoted to the Nanzhuangtou site with a pottery-associated ${ }^{14} \mathrm{C}$ date of $\sim 10,200 \mathrm{BP}$, while the data on the Hutouliang site are given in a few paragraphs (see Guo and Li 2002:199). It is worth mentioning that the Hutouliang site consists of at least 9 localities (e.g. Gai and Wei 1977) ranging in ${ }^{14} \mathrm{C}$ age from $\sim 10,690$ to $\sim 5625 \mathrm{BP}$, and without details of the site's provenance it is impossible to understand the validity of Yasuda's (2002) and Liu and Chang's (2012) conclusions. Unfortunately, Liu and Chang (2012) ignored a critical evaluation of the chronology for the Hutouliang site by Kuzmin (2006) as well as views expressed by Chinese archaeologists before (e.g. Zhao 1998) and after (e.g. Lu 2010) the announcement of the "early" pottery-related ${ }^{14} \mathrm{C}$ date from Hutouliang by Yasuda (2002).

Based on the evaluation of new data from China, it can be concluded that the disturbed nature of the Xianrendong Cave cultural layers does not allow us to accept the ${ }^{14} \mathrm{C}$ dates associated with the pottery older than $\sim 15,000 \mathrm{BP}$, and most likely older than 13,500 BP (e.g. MacNeish et al. 1998:39). MacNeish (1999:238) concluded that the earliest pottery phase Xian Ren in Jiangxi Province of China “...dates between 11,200 and 14,000 BP.” The best-proven site in southern China with the oldest pottery is still Yuchanyan Cave, dated to 14,800 BP (Boaretto et al. 2009; see review in Kuzmin 2010b). In northern China, the Nanzhuangtou site with an associated ${ }^{14} \mathrm{C}$ date of $\sim 10,200 \mathrm{BP}$ is the earliest reliable evidence of pottery-making (e.g. Wu and Zhao 2003:19; Kuzmin 2006).

\section{CONCLUSION}

It seems that the "agricultural” Neolithic has its origin in Levantine societies at $11,500-12,500$ cal BP, with a subsequent spread after $\sim 9000 \mathrm{cal}$ BP toward central/western Europe and some regions in central and south Asia. The "pottery" Neolithic is to a major extent an independent invention, with several "centers" for the emergence of pottery-making technologies identified after 18,300 cal BP throughout Eurasia. Two main (and very different!) ways in the Neolithization process in Eurasia are therefore obvious (e.g. Kuzmin 2010a). Recently, Shelach (2012:1645) mentioned "... a fundamental difference in the socioeconomic development of the two regions [East Asia and Levant]." Probably, the clearer term for the pre-agriculture "Neolithic" complexes in East Asia would be "pottery-bearing hunter-gatherers" or the like, similar to the Jomon in Japan and Chulmun in Korea (e.g. Barnes 1999:71). 


\section{Two Trajectories in the Neolithization of Eurasia}

A further in-depth analysis of the pottery-agriculture relationship in Eurasia should be conducted after rigorous evaluation of the existing information and with non-biased viewpoints, in order not to "mix apples and oranges." The concept of "center(s)" for the origin and spread of pottery in nonagricultural societies of Eurasia contradicts the primary evidence.

\section{ACKNOWLEDGMENTS}

I am grateful to several colleagues for discussion of the issues related to the Neolithization of Eurasia: Profs Peter S Bellwood, Mihael Budja, Charles FW Higham, Peter Jordan, Yuri B Tsetlin, and Aleksander A Vybornov; and Drs Dorian Q Fuller, Elena Y Lebedeva, and Susan G Keates. This study was supported by the Russian Foundation for Basic Sciences (RFFI), grants 96-06-80688, 9906-80348, 06-06-80258, 06-06-85511, 09-06-08021, 10-06-00005, 12-06-00045, and 13-06-00363; and by Siberian Branch of the Russian Academy of Sciences (SB RAS), Project "GIS Modeling and Spatial Analysis of Environmental Systems and Their Components,” Program IV.31.2; and joint SB RAS - FEB RAS Partnership Integrative Project No. 73.

\section{REFERENCES}

Akkermans PMMG, Schwartz GM. 2003. The Archaeology of Syria: From Complex Hunter-Gatherers to Early Urban Societies (c. 16,000 - 300 BC). Cambridge: Cambridge University Press. $467 \mathrm{p}$.

Anthony DW. 2007. The Horse, the Wheel, and Language: How Bronze-Age Riders from the Eurasian Steppes Shaped the Modern World. Princeton: Princeton University Press. $553 \mathrm{p}$.

Aseev IV. 2003. Yugo-Vostochnaya Sibir v Epokhu Kamnya i Metalla [The Southeastern Siberia in the Stone and Metal Epochs]. Novosibirsk: Institute of Archaeology \& Ethnography Press. 206 p. In Russian.

Barnes GL. 1999. The Rise of Civilization in East Asia: The Archaeology of China, Korea and Japan. London: Thames \& Hudson. 288 p.

Bar-Yosef O. 2001. The world around Cyprus: from EpiPaleolithic foragers to the collapse of the PPNB civilization. In: Swiny S, editor. The Earliest Prehistory of Cyprus: From Colonization to Exploitation. Boston: American School of Oriental Research. p 129-64.

Boaretto E, Wu X, Yuan J, Bar-Yosef O, Chu V, Pan Y, Liu K, Cohen D, Jiao T, Li S, Gu H, Goldberg P, Weiner S. 2009. Radiocarbon dating of charcoal and bone collagen associated with early pottery at Yuchanyan Cave, Hunan Province, China. Proceedings of the National Academy of Sciences of the USA 106(24): 9595-600.

Bocquet-Appel JP, Naji S, Linden MV, Kozlowski J. 2012. Understanding the rates of expansion of the farming system in Europe. Journal of Archaeological Science 39(2):531-46.

Bonsall C, Cook GT, Hedges REM, Higham TFG, Pickard C, Radovanović I. 2004. Radiocarbon and stable isotope evidence of dietary change from the Mesolithic to the Middle Ages in the Iron Gates: new results from Lepenski Vir. Radiocarbon 46(1):293-300.

Brown A. 2007. Dating the onset of cereal cultivation in Britain and Ireland: the evidence from charred cereal grains. Antiquity 81(314):1042-52.

Chairkina NM, Kosinskaia LN. 2009. Early hunter-gatherer ceramics in the Urals and Western Siberia. In: Jordan P, Zvelebil M, editors. Ceramics before Farming: The Dispersal of Pottery among Prehistoric Eurasian Hunter-Gatherers. Walnut Creek: Left Coast Press. p 209-35.

Childe VG. 1935. Changing methods and aims in prehistory. Presidential address for 1935. Proceedings of the Prehistoric Society 1:1-15.

Childe VG. 1954. New Light on the Most Ancient East. 4th edition. New York: F.A. Praeger. 255 p.

Clark JGD. 1965. Radiocarbon dating and expansion of farming from the Near East over Europe. Proceedings of the Prehistoric Society 31:57-73.

Crawford GW. 2011. Advances in understanding early agriculture in Japan. Current Anthropology 52(S4): S331-45.

Davison K, Dolukhanov P, Sarson GR, Shukurov A. 2006. The role of waterways in the spread of the Neolithic. Journal of Archaeological Science 33(5): 641-52.

Davison K, Dolukhanov PM, Shukurov A, Sarson RG, Zaitseva GI. 2007. Multiple sources of the European Neolithic: mathematical modelling constrained by radiocarbon dates. Quaternary International 203(1-2): $10-18$.

Denham T. 2011. Early agriculture and plant domestication in New Guinea and island Southeast Asia. Current Anthropology 52(S4):S379-95.

Dolukhanov P, Shukurov A. 2004. Modelling the Neolithic dispersal in northern Eurasia. Documenta Praehistorica 31:35-47.

Dolukhanov PM, Mazurkevich AM, Shukurov AM. 2009. Early pottery makers in Eastern Europe: centres of origins, subsistence and dispersal. In: Jordan P, Zvelebil M, editors. Ceramics before Farming: The Dispersal of Pottery among Prehistoric Eurasian 


\section{Y V Kuzmin}

Hunter-Gatherers. Walnut Creek: Left Coast Press. p 237-53.

Forenbaher S, Miracle P. 2005. The spread of farming in the Eastern Adriatic. Antiquity 79(305):514-28.

Frachetti MD, Spengler RN, Fritz GJ, Mar'yashev AN. 2010. Earliest direct evidence for broomcorn millet and wheat in the central Eurasian steppe region. Antiquity 84(326):993-1010.

Fuller DQ. 2011. Finding plant domestication in the Indian subcontinent. Current Anthropology 52(S4): S347-62.

Fuller DQ, Rowlands M. 2011. Ingestion and food technologies: maintaining differences over the long-term in West, South, and East Asia. In: Wilkinson TC, Sherratt S, Bennet J, editors. Interweaving Worlds: Systematic Interactions in Eurasia, 7th to 1st Millennia BC. Oakville: Oxbow Books. p 37-60.

Fuller DQ, Boivin N, Korisettar R. 2007a. Dating the Neolithic of South India: new radiometric evidence for key economic, social and ritual transformations. Antiquity 81(313):755-78.

Fuller DQ, Harvey E, Qin L. 2007b. Presumed domestication? Evidence for wild rice cultivation and domestication in the fifth millennium BC of the Lower Yangtze region. Antiquity 81(312):316-31.

Gai P, Wei Q. 1977. Discovery of the Late Palaeolithic site at Hutouliang, Hebei. Vertebrata PalAsiatica 15(4):287-300. In Chinese with English title.

Gkiasta M, Russel T, Shennan S, Steele J. 2003. Neolithic transition in Europe: the radiocarbon record revisited. Antiquity 77(295):45-62.

Guo R, Li J. 2002. The Nanzhuangtou and Hutouliang sites: exploring the beginnings of agriculture and pottery in North China. In: Yasuda Y, editor. The Origins of Pottery and Agriculture. New Delhi: Roli Books \& Lustre Press. p 193-204.

Hanks BK, Epimakhov AV, Renfrew AC. 2007. Toward a refined chronology for the Bronze Age of the southern Urals, Russia. Antiquity 81(312):353-67.

Harris DR. 2010. Origins of Agriculture in Western Central Asia: An Environmental-Archaeological Study. Philadelphia: University of Pennsylvania Museum of Archaeology and Anthropology. 304 p.

Hartz S, Lüth F, Terberger T, editors. 2011. Early Pottery in the Baltic - Dating, Origin and Social Context. Darmstadt/Mainz: Philipp von Zabern Verlag. 500 p.

Hartz S, Kostyleva E, Piezonka H, Terberger T, Tsydenova N, Zhilin MG. 2012. Hunter-gatherer pottery and charred residue dating: new results on early ceramics in the north Eurasian forest zone. Radiocarbon 54(34):1033-48.

Higham CFW. 2002. Early Cultures of Mainland Southeast Asia. Chicago: Art Media Resources. 375 p.

Higham CFW, Xie G, Lin Q. 2011. The prehistory of a Friction Zone: first farmers and hunters-gatherers in Southeast Asia. Antiquity 85(328):529-43.

Jarrige J-F, Jarrige C, Quivron G. 2006. Mehrgarh
Neolithic: the updated sequence. In: Jarrige C, Lefevre V, editors. South Asian Archaeology 2001. Paris: Editions Recherché sur les Civilisations. p 129-41.

Jordan P, Zvelebil M, editors. 2009. Ceramics before Farming: The Dispersal of Pottery among Prehistoric Eurasian Hunter-Gatherers. Walnut Creek: Left Coast Press. 589 p.

Kremenetski KV. 2003. Steppe and forest-steppe belt of Eurasia: Holocene environmental history. In: Levine M, Renfrew C, Boyle K, editors. Prehistoric Steppe Adaptation and the Horse. Cambridge: McDonald Institute for Archaeological Research. p 11-27.

Kuzmin YV. 2006. Chronology of the earliest pottery in East Asia: progress and pitfalls. Antiquity 80(308): 362-71.

Kuzmin YV. 2009. Radiocarbon and Old World archaeology: shaping a chronological framework. Radiocarbon 51(1):149-72.

Kuzmin YV. 2010a. The Neolithic of the Russian Far East and neighbouring East Asia: definition, chronology, and origins. Bulletin of the Indo-Pacific Prehistory Association 30:157-62.

Kuzmin YV. 2010b. The origin of pottery in East Asia and its relationship to environmental changes in the Late Glacial. Radiocarbon 52(2):415-20.

Kuzmin YV, Vetrov VM. 2007. The earliest Neolithic complex in Siberia: the Ust-Karenga 12 site and its significance for the Neolithisation process in Eurasia. Documenta Praehistorica XXXIV:9-20.

Kuzmin YV, Shewkomud IY, Dementiev VN. 2005. Middle Amur Plain development in ancient times, and anthropogenic impact on its landscapes in the Neolithic and Middle Ages. Geografiya i Prirodnye Resursy 3:85-9. In Russian with English title.

Kuzmin YV, Jull AJT, Burr GS. 2009. Major patterns in the Neolithic chronology of East Asia: issues of the origin of pottery, agriculture, and civilization. Radiocarbon 51(3):891-903.

Lebedeva EY. 2005. Arkheobotanika i izuchenie zemledeliya epokhi bronzy v Vostochnoi Evrope [Archaeobotany and study of the Bronze Age agriculture in Eastern Europe]. In: Dobrovolskaya MV, editor. OPUS: Mezhdistsiplinarnye Issledovaniya $v$ Arkheologii. Vypusk 4. Moscow: Institute of Archaeology, Russian Academy of Sciences. p 50-68. In Russian.

Lee GA. 2011. The transition from foraging to farming in prehistoric Korea. Current Anthropology 52(S4): S307-29.

Lemmen C, Gronenborn D, Wirtz KW. 2011. A simulation of the Neolithic transition in Western Eurasia. Journal of Archaeological Science 38(12):3459-70.

Lillie MC, Richards M. 2000. Stable isotope analysis and dental evidence of diet at the Mesolithic-Neolithic transition in Ukraine. Journal of Archaeological Science 27(10):965-72.

Lillie M, Budd C, Potekhina I, Hedges R. 2009. The radiocarbon reservoir effect: new evidence from the 


\section{Two Trajectories in the Neolithization of Eurasia}

cemeteries of the middle and lower Dnieper basin, Ukraine. Journal of Archaeological Science 36(2): 256-64.

Liu L, Chang X. 2012. The Archaeology of China: From the Late Paleolithic to the Early Bronze Age. New York: Cambridge University Press. 475 p.

Lu H, Zhang J, Liu KB, Wu N, Li Y, Zhou K, Ye M, Zhang T, Zhang H, Yang X, Shen L, Li Q. 2009. Earliest domestication of common millet (Panicum miliaceum) in East Asia extended to 10,000 years ago. Proceedings of the National Academy of Sciences of the USA 106(18):7367-72.

Lu TL-D. 2010. Early pottery in South China. Asian Perspectives 49(1):1-42.

Lubbock J. 1878. Pre-Historic Times. 4th edition. New York: D. Appleton \& Co. 655 p.

MacNeish RS. 1999. A Paleolithic-Neolithic sequence from South China Jiangxi Province, PRC. In: Omoto $\mathrm{K}$, editor. Interdisciplinary Perspectives on the Origins of the Japanese. Kyoto: International Research Center for Japanese Studies. p 233-55.

MacNeish RS, Libby JG, editors. 1995. Origins of Rice Agriculture: The Preliminary Report of the SinoAmerican Jiangxi (PRC) Project SAJOR. El Paso: University of Texas at El Paso. 99 p.

MacNeish RS, Cunnar G, Zhao Z, Libby JG. 1998. ReRevised Second Annual Report of the Sino-American Jiangxi (PRC) Origin of Rice Project SAJOR. Andover: Andover Foundation for Archaeological Research, Ltd. 83 p.

Manning SW, McCartney C, Kromer B, Stewart ST. 2010. The earlier Neolithic in Cyprus: recognition and dating of a pre-pottery Neolithic A occupation. Antiquity 84(325):693-706.

Marinova E. 2007. Archaeobotanical data from the early Neolithic of Bulgaria. In: Colledge S, Connolly J, editors. The Origins and Spread of Domestic Plants in Southwest Asia and Europe. Walnut Creek: Left Coast Press. p 93-109.

Matyushin G. 2003. Problems of inhabiting central Eurasia: Mesolithic-Eneolithic exploitation of the central Eurasian steppes. In: Levine M, Renfrew C, Boyle K, editors. Prehistoric Steppe Adaptation and the Horse Cambridge: McDonald Institute for Archaeological Research. p 367-93.

Mertz VK. 2008. Periodizatsiya Golotsenovykh Kompleksov Severnogo i Tsentralnogo Kazakhstana po Materialam Mnolosloinoi Stoyanki Shiderty 3 [Periodization of the Holocene Complexes of Northern and Central Kazakhstan Based on Materials from the Multilayered Site Shiderty 3]. Synopsis of PhD dissertation. Kemerovo: Kemerovo State University. 16 p. In Russian.

Moore AMT, Hillman GC, Legge AJ. 2000. Village on the Euphrates: From Foraging to Farming at Abu Hureyra. Oxford: Oxford University Press. 585 p.

Nakamura T, Taniguchi Y, Tsuji S, Oda H. 2001. Radio- carbon dating of charred residues on the earliest pottery in Japan. Radiocarbon 43(2B):1129-38.

Nesbitt M. 1999. When and where did domesticated cereals first occur in southwest Asia? In: Cappers RTJ, Bottema S, editors. The Dawn of Farming in the Near East. Berlin: Ex Oriente. p 113-32.

Nguyen KS, Pham MH, Tong TT. 2004. Northern Vietnam from the Neolithic to the Han period. In: Glover I, Bellwood P, editors. Southeast Asia: From Prehistory to History. New York: RoutledgeCurzon. p 177208.

Özdoğan M. 2011. Archaeological evidence on the westward expansion of farming communities from eastern Anatolia to the Aegean and the Balkans. Current Anthropology 52(S4):S415-30.

Paz V. 2005. Rock shelters, caves, and archaeobotany in island Southeast Asia. Asian Perspectives 44(1):10718.

Peltenburg E, Croft P, Jackson A, McCartney C, Murray MA. 2001. Well-established colonists: Mylouthkia 1 and the Cypro-Pre-Pottery Neolithic B. In: Swiny S, editor. The Earliest Prehistory of Cyprus: From Colonization to Exploitation. Boston: American School of Oriental Research. p 61-93.

Piezonka H. 2011. The earliest pottery east of the Baltic Sea. In: Hartz S, Lüth F, Terberger T, editors. Early Pottery in the Baltic - Dating, Origin and Social Context. Darmstadt/Mainz: Philipp von Zabern Verlag. p 301-46.

Pinhasi R, Fort J, Ammerman AJ. 2005. Tracing the origin and spread of agriculture in Europe. PLoS Biology 3(12):e410, doi:10.1371/journal.pbio.0030410.

Price TD. 2000. Europe's first farmers: an introduction. In: Price TD, editor. Europe's First Farmers. Cambridge: Cambridge University Press. p 1-18.

Price TD, Bar-Yosef O, editors. 2011. The origins of agriculture: new data, new ideas. Current Anthropology 52(S4):S161-S512.

Reimer PJ, Baillie MGL, Bard E, Bayliss A, Beck JW, Blackwell PG, Bronk Ramsey C, Buck CE, Burr GS, Edwards RL, Friedrich M, Grootes PM, Guilderson TP, Hajdas I, Heaton TJ, Hogg AG, Hughen KA, Kaiser KF, Kromer B, McCormac FG, Manning SW, Reimer RW, Richards DA, Southon JR, Talamo S, Turney CSM, van der Plicht J, Weyhenmeyer CE. 2009. IntCal09 and Marine09 radiocarbon age calibration curves, $0-50,000$ years cal BP. Radiocarbon 51(4): 1111-50.

Renfrew C. 1969. Trade and culture process in European prehistory. Current Anthropology 10(2-3):151-69.

Renfrew C. 1973. Before Civilization: The Radiocarbon Revolution and Prehistoric Europe. New York: A.A. Knopf. 292 p.

Russel TM. 2004. The Spatial Analysis of Radiocarbon Databases: The Spread of the First Farmers in Europe and of the Fat-Tailed Sheep in Southern Africa. Oxford: Archaeopress. $390 \mathrm{p}$. 


\section{Y V Kuzmin}

Ryabogina NE, Ivanov CN. 2011. Ancient agriculture in Western Siberia: problems of argumentation, paleoethnobotanic methods, and analysis of data. Archaeology, Ethnology \& Anthropology of Eurasia 39/4:96106.

Shelach G. 2012. On the invention of pottery. Science 336(6089):1644-5.

Spriggs M. 2003. Chronology of the Neolithic transition in island Southeast Asia and the Western Pacific: a view from 2003. The Review of Archaeology 24(2): 57-80.

Thomas J. 1993. Discourse, totalization, and the Neolithic. In: Tilly C, editor. Interpretative Archaeology. Oxford: Berg. p 357-94.

Timofeev VI, Zaitseva GI, Dolukhanov PM, Shukurov AM. 2004. Radiouglerodnaya Khronologiya Neolita Severnoi Evrazii [Radiocarbon Chronology of the Neolithic of Northern Eurasia]. St. Petersburg: Teza Publishing. 157 p. In Russian.

Trigger BG. 2006. A History of Archaeological Thought. 2nd edition. Cambridge: Cambridge University Press. $710 \mathrm{p}$.

Tsetlin YB. 2008. The Center of the Russian Plain in the Neolithic Age: Decoration of Clay Vessels and Methods for the Periodization of Cultures. Tula: Grif i K Publishers. 352 p. In Russian with English summary.

Tsvetkova NA. 2011. Ranny neolit Verkhnego Povolzhya: nekotorye itogi izucheniya [The Early Neolithic of the Upper Volga River region: some results of investigations]. Rossiisky Arkheologichesky Ezhegodnik 1:148-82. In Russian with English summary.

Tsybiktarov AD. 2003. Central Asia in the Bronze and Early Iron Ages (problems of ethnocultural history of Mongolia and southern Transbaikal in the middle of the II-nd - first part of the I-st millennia BC). Archaeology, Ethnology \& Anthropology of Eurasia 1(13): 80-97.

Vybornov AA. 2008. Neolit Volgo-Kamya [The Neolithic of the Volga-Kama Region]. Samara: Samara State Pedagogical University. 490 p. In Russian with English summary.

Whittle A. 1996. Europe in the Neolithic: The Creation of New Worlds. Cambridge: Cambridge University
Press. 443 p.

Wu X, Zhao C. 2003. Chronology of the transition from Palaeolithic to Neolithic in China. The Review of Archaeology 24(2):15-20.

Wu X, Zhang C, Goldberg P, Cohen D, Pan Y, Arpin T, Bar-Yosef O. 2012. Early pottery at 20,000 years ago in Xianrendong Cave, China. Science 336(6089): 1696-1700.

Yanushevich ZV. 1989. Agricultural evolution north of the Black Sea from the Neolithic to the Iron Age. In: Harris DR, Hillman GC, editors. Foraging and Farming: The Evolution of Plant Exploitation. London: Unwin Hyman. p 607-19.

Yasuda Y. 2002. Origins of pottery and agriculture in East Asia. In: Yasuda Y, editor. The Origins of Pottery and Agriculture. New Delhi: Roli Books \& Lustre Press. p 119-42.

Zaitseva G, Skripkin V, Kovaliukh N, Possnert G, Dolukhanov P, Vybornov A. 2009. Radiocarbon dating of Neolithic pottery. Radiocarbon 51(2):795-801.

Zaretskaya NE, Kostyliova EL. 2008. Radiocarbon chronology of the initial period of the Upper Volga Early Neolithic culture (on the basis of finds from Sakhtysh2a site). Rossiiskaya Arkheologiya 1:5-14. In Russian with English abstract.

Zhang C, Hung HC. 2010. The emergence of agriculture in southern China. Antiquity 84(323):11-25.

Zhang C, Hung HC. 2012. Later hunter-gatherers in southern China, 18 000-3 000 BC. Antiquity 86(331): 11-29.

Zhao C. 1998. New achievements in the study of the transitional period from the Palaeolithic to the Neolithic in China. Documenta Praehistorica XXV:27-36.

Zilhão J. 2000. From the Mesolithic to the Neolithic in the Iberian Peninsula. In: Price TD, editor. Europe's First Farmers. Cambridge: Cambridge University Press. p 144-82.

Zvelebil M. 1998. Agricultural frontiers, Neolithic origins, and the transition to farming in the Baltic Basin. In: Zvelebil M, Domańska L, Dennell R, editors. Harvesting the Sea, Farming the Forest: The Emergence of Neolithic Societies in the Baltic Region. Sheffield: Sheffield Academic Press. p 9-27. 